\title{
Reported Cases of Serotonin Syndrome in MDMA Users in FAERS Database
}

\author{
Tigran Makunts ${ }^{1,2 *}$, Lisa Jerome ${ }^{1}$, Ruben Abagyan ${ }^{2}$ and Alberdina de Boer ${ }^{1}$ \\ ${ }^{1}$ MAPS Public Benefit Corporation, San Jose, CA, United States, ${ }^{2}$ Skaggs School of Pharmacy and Pharmaceutical \\ Sciences, University of California, San Diego, San Diego, CA, United States
}

3,4-Methylenedioxymethamphetamine (MDMA), is investigated as a treatment for posttraumatic stress disorder and other anxiety-related conditions in multiple placebocontrolled and open label studies. MDMA-assisted therapy is projected for approval by the United States Food and Drug Administration (FDA) and other regulatory agencies worldwide within the next few years. MDMA is a monoamine releaser and uptake inhibitor affecting serotonin, potentially increasing the risk of serotonin syndrome (SS). No instances of SS have occurred in clinical trials. The relatively small number of patients in controlled trials warranted a survey of FDA Adverse Event Reporting System data for the occurrence of SS in a larger database. We found 20 SS cases in people exposed

OPEN ACCESS

Edited by:

Mirko Manchia,

University of Cagliari, Italy

Reviewed by:

Matthias E. Liechti,

University Hospital of

Basel, Switzerland

John Martin Corkery,

University of Hertfordshire,

United Kingdom

*Correspondence:

Tigran Makunts

tmakunts@health.ucsd.edu

Specialty section:

This article was submitted to

Psychopharmacology,

a section of the journal

Frontiers in Psychiatry

Received: 29 November 2021 Accepted: 28 December 2021 Published: 24 January 2022

Citation:

Makunts T, Jerome L, Abagyan R and de Boer A (2022) Reported Cases of Serotonin Syndrome in MDMA Users in FAERS Database.

Front. Psychiatry 12:824288. doi: 10.3389/fpsyt.2021.824288 to MDMA, all of which had also taken one or more substances with serotonergic properties in addition to MDMA, including amphetamines, stimulants, and opioids. There were no cases of SS associated with MDMA where MDMA was the sole reported compound taken.

Keywords: serotonin syndrome, MDMA (3, 4- methylenedioxymethamphetamine), FAERS database, surveillance system, case reports [publication type]

\section{INTRODUCTION}

In the European Union and the United States, 3,4-methylenedioxymethamphetamine (MDMA) is currently a schedule I controlled substance (Class A in the United Kingdom). The interest in MDMA use in psychiatry has solidified and is growing following publications of results from multiple controlled trials including a Phase 3 study for MDMA assisted therapy for post-traumatic stress disorder (PTSD) (1-4).

MDMA's psychoactive properties are due to multiple mechanisms that modulate monoamine neurotransmission, including release and reuptake of serotonin, dopamine and norepinephrine (5-8). Proposed therapeutic mechanisms of MDMA may include increased ability to confront upsetting memories, supporting fear-extinction learning and increased interpersonal closeness (9-11). Adverse events observed in controlled trials included transient hypertension, muscle tightness, decreased appetite, nausea, hyperhidrosis and feeling cold $(1,12)$.

Serotonin syndrome (SS) is a potentially life-threatening condition resulting from serotonergic over-activity at synapses of the central and peripheral nervous systems usually involving serotonergic medications (13). SS manifests itself through a range of mild to severe symptoms. Mild symptoms include akathisia and tremors, and severe symptoms include hyperthermia and muscular rigidity, which can be life-threatening (14).

Although not observed under controlled conditions, MDMA use beyond research settings has been associated with SS in case reports and toxicology studies (15-18). The vast majority of SS 
clinical case reports in published literature include a combination of two or more serotonergic agents including various classes of antidepressants, and other medications with serotonergic activity such as opioids (tramadol), antibiotics (linezolid), antihistamines (diphenhydramine), and atypical antipsychotics (19-24).

Given the high percentage of the PTSD population for whom serotonin modulating therapeutics are prescribed (25, 26) and the high prevalence of other PTSD comorbid conditions, including substance use (27), depression (28), anxiety (29), sleep (30), and pain disorders (31) treated by serotonergic drugs, further exploration of MDMA related Adverse Events (AE) reports from the drug safety surveillance database in the FDA Adverse Event Reporting System (FAERS) is warranted.

In this study, we evaluated individual cases listing MDMA use associated with SS and reported to FAERS through MedWatch (32). We evaluated reports for the presence of MDMA as the sole reported compound, and for the presence of any additional substances or medications, particularly those that might increase the risk of SS due to their inherent serotonergic activity.

\section{METHODS}

\section{FDA Adverse Event Reporting System}

FAERS is an AE case repository for drugs and biologics reported to the FDA through MedWatch $(32,33)$. Cases include voluntary AE reports by consumers, healthcare professionals, legal representatives, and manufacturers.

FAERS was initially intended for post-marketing drug and biologic surveillance. However, it has historically included drugs pending approval and even schedule I controlled substances. Since there are no phase 4 trials for the latter, FAERS is an important source of safety data, as it provides meaningful safety signals which may help in diagnosing and mitigating illicit drug toxicity cases in the real world. Additionally, reporting use of illegal or unapproved substances to FAERS is important because they may often be the culprit of an adverse event as is often seen in polypharmacy cases.

\section{Combining and Normalizing Data Sets}

Quarterly FAERS/AERS data sets were downloaded individually from the FDA's public repository and saved in a dollar-sign separated text format. Each quarterly dataset includes a data subset which refers to a specific variable or variables in the AE report (demographics, drug, indication, outcome, reaction, report source, therapy). The $\mathrm{AE}$ reports were recompiled using the case numbers common in each of the subsets. The study covered over 16 million reports from FAERS from September 2004 through June 2021. Because incomplete reporting and paucity of data did not allow a uniform format in all quarters/years, we standardized the data sets to create a consistent structure $(34,35)$ with blank tables replacing missing values. Unix/Linux code was used in data restructuring and manipulation. A total of 16,014,341 AE reports were obtained.

\section{RESULTS}

There were 1,143 AE reports which included MDMA in FAERS/AERS; 20 of the reports listing MDMA were reports of SS. Interestingly FAERS/AERS contained only one case of MDMA (reported as ecstasy) was identified as the sole responsible compound; a report of cardiomyopathy. Nineteen of the reports were submitted by healthcare professionals, while one report was submitted by the consumer (a voluntary report by an individual). There were no reports of SS where MDMA was identified as the sole responsible compound. The remainder of the MDMA AE reports $(n=1,142)$ included MDMA and at least one or more concomitant drug. The most common class of drugs reportedly taken along with MDMA in cases of SS were amphetamines (12 reports), followed by opioids (10 reports), benzodiazepines and sedative hypnotics (8 reports), cannabis or tetrahydrocannabinol (THC) (8 reports), selective serotonin reuptake inhibitors (SSRIs) (6 reports), monoamine oxidase inhibitors (MAOIs) (4 reports), 2nd generation antipsychotics (3 reports), cocaine (2 reports), alcohol (2 reports), ergot alkaloids (1 report), serotoninnorepinephrine reuptake inhibitors (SNRIs) (1 report), and ketamine (1 report) (Tables 1,2 ).

Seventeen out of 20 cases included two or more concomitant psychoactive substances. The Pubmed library was queried (using SS and MDMA, midomafetamine, 3,4-methylenedioxymethamphetamine, 3,4-methylenedioxymethamphetamine, molly, and ecstasy terms), to confirm whether any of the presented cases were present in the literature, and no published reports were found, possibly due the MDMA being designated as not the primary suspect in all the cases.

\section{DISCUSSION}

In this study, we evaluated SS cases associated with MDMA use reported to the FDA using the FAERS system. We found no reports of SS in cases where MDMA was the sole reported drug, which confirmed the observed lack of SS in clinical trials. Additionally, we observed a limited number of 20 cases of SS associated with use of MDMA reported in the last $\sim 17$ years. All of those cases listed additional serotonergic psychoactive drugs, with $85 \%$ of the reports including at least two other drugs with serotonergic properties. It should be noted that none of the reports considered MDMA the "primary suspect" (PS) of the AE adjudicated by the reporter. There is a possibility that MDMA contributed to the AE profile through CYP2D6-mediated drugdrug interaction $(36,37)$. Considering the large number of people who report using ecstasy, estimated by the United Nations Office of Drugs and Crime to be nearly twenty million people (38), the number of MDMA FAERS/AERS reports was surprisingly low.

\section{Study Limitations}

Since reporting to FAERS is mostly voluntary, apart from spontaneous reports forwarded from the manufacturers/authorization holders, the data set represents only a subset of actual cases and therefore the FAERS case frequencies 
TABLE 1 | Individual cases of serotonin syndrome.

\begin{tabular}{|c|c|c|c|c|c|c|c|}
\hline & Age & Sex & Country & $\begin{array}{l}\text { Concomitant } \\
\text { medications }\end{array}$ & Adverse events & Outcome & Reported by \\
\hline 1 & 24 & $M$ & Germany & $\begin{array}{l}\text { PS-Clozapine } \\
\text { SS-MDMA } \\
\text { C-amisulpride } \\
\text { C-zopiclone } \\
\text { C-olanzapine } \\
\text { C-lorazepam }\end{array}$ & $\begin{array}{l}\text { Serotonin syndrome } \\
\text { Convulsions } \\
\text { Psychotic disorder }\end{array}$ & OT & $\mathrm{MD}$ \\
\hline 2 & 25 & $M$ & Turkey & $\begin{array}{l}\text { PS-fentanyl } \\
\text { SS-ephedrine } \\
\text { SS-MDMA } \\
\text { SS-ergot alkaloids } \\
\text { SS-marijuana } \\
\text { C-bupivacaine } \\
\text { C-midazolam } \\
\text { C-propofol } \\
\text { C-vecuronium }\end{array}$ & Serotonin syndrome & $\mathrm{HO}$ & MD \\
\hline $3^{*}(2)$ & 20 & $\mathrm{~F}$ & UK & $\begin{array}{l}\text { PS-oxycodone } \\
\text { SS-MDMA }\end{array}$ & Serotonin Syndrome & $\mathrm{DE}$ & $\mathrm{CN}$ \\
\hline 4 & 24 & $M$ & Australia & $\begin{array}{l}\text { PS-dextroamphetamine and } \\
\text { amphetamine salts } \\
\text { SS-MDMA } \\
\text { SS-methamphetamine } \mathrm{HCl} \\
\text { SS-moclobemide }\end{array}$ & Serotonin Syndrome & $\mathrm{DE}$ & Other HP \\
\hline 5 & 45 & $M$ & Australia & $\begin{array}{l}\text { PS-dextroamphetamine and } \\
\text { amphetamine salts } \\
\text { SS-MDMA }\end{array}$ & $\begin{array}{l}\text { Serotonin syndrome } \\
\text { Drug interaction } \\
\text { Drug toxicity }\end{array}$ & $\mathrm{DE}$ & Other HP \\
\hline 6 & 31 & $M$ & Australia & $\begin{array}{l}\text { PS-dextroamphetamine and } \\
\text { amphetamine salts } \\
\text { SS-MDMA } \\
\text { SS-methamphetamine } \mathrm{HCl} \\
\text { SS-moclobemide } \\
\text { SS-THC }\end{array}$ & Serotonin syndrome & $\mathrm{DE}$ & Other HP \\
\hline 7 & 25 & $\mathrm{~F}$ & Australia & $\begin{array}{l}\text { PS-dextroamphetamine and } \\
\text { amphetamine salts } \\
\text { SS-MDMA } \\
\text { SS-methamphetamine } \mathrm{HCl}\end{array}$ & Serotonin syndrome & $\mathrm{DE}$ & Other HP \\
\hline 8 & 24 & $M$ & US & $\begin{array}{l}\text { PS-Lithium carbonate } \\
\text { SS-MDMA } \\
\text { SS-fentanyl } \\
\text { SS-midazolam } \\
\text { SS-phenelzine } \\
\text { SS-propofol } \\
\text { SS- } \\
\text { suxamethonium (succinylcholine) }\end{array}$ & $\begin{array}{l}\text { Blood CPK increased } \\
\text { Clonus } \\
\text { Hyperhidrosis } \\
\text { lleus } \\
\text { Loss of consciousness } \\
\text { Muscle twitching } \\
\text { Mydriasis } \\
\text { Myoclonus } \\
\text { Nystagmus } \\
\text { Serotonin syndrome } \\
\text { Tachypnea }\end{array}$ & $\mathrm{HO}, \mathrm{OT}$ & Other HP \\
\hline $9^{*}(2)$ & 16 & $M$ & US & $\begin{array}{l}\text { PS-APAP hydrocodone } \\
\text { SS-amphetamine } \\
\text { SS-cocaine } \\
\text { SS-marijuana } \\
\text { SS-MDMA } \\
\text { SS-methamphetamine } \mathrm{HCl}\end{array}$ & $\begin{array}{l}\text { Disseminated intravascular } \\
\text { coagulation } \\
\text { Hepatorenal failure } \\
\text { Hyperthermia malignant } \\
\text { Hypoglycemia } \\
\text { Hypoxic ischemic } \\
\text { encephalopathy } \\
\text { Intentional drug misuse } \\
\text { Multi organ failure } \\
\text { Multiple drug Overdose } \\
\text { intentional } \\
\text { Rhabdomyolysis } \\
\text { Serotonin syndrome } \\
\text { Shock }\end{array}$ & $\mathrm{DE}$ & $\mathrm{MD}$ \\
\hline
\end{tabular}


TABLE 1 | Continued

\begin{tabular}{|c|c|c|c|c|c|c|c|}
\hline & Age & Sex & Country & $\begin{array}{l}\text { Concomitant } \\
\text { medications }\end{array}$ & Adverse events & Outcome & Reported by \\
\hline $10^{*}(2)$ & 28 & M & Australia & $\begin{array}{l}\text { PS-sertraline } \\
\text { I-ethanol } \\
\text { I-methamphetamine } \\
\text { I-MDMA } \\
\text { I-THC }\end{array}$ & $\begin{array}{l}\text { Serotonin syndrome } \\
\text { Back injury } \\
\text { Head injury } \\
\text { Road traffic accident }\end{array}$ & DE, OT & Other HP \\
\hline 12 & 32 & M & Australia & $\begin{array}{l}\text { PS-alprazolam } \\
\text { C-diazepam } \\
\text { C-MDMA } \\
\text { C-Methadone } \\
\text { C-methamphetamine }\end{array}$ & $\begin{array}{l}\text { Serotonin syndrome } \\
\text { Toxicity to various agents }\end{array}$ & $\mathrm{DE}, \mathrm{HO}$ & $\mathrm{MD}$ \\
\hline 14 & 21 & M & Australia & $\begin{array}{l}\text { PS-diazepam } \\
\text { SS-MDMA } \\
\text { SS-methamphetamine HCl } \\
\text { SS-amphetamine } \\
\text { SS-codeine } \\
\text { SS-fluoxetine } \\
\text { SS-ketamine } \\
\text { SS-morphine } \\
\text { SS-Sertraline } \\
\text { SS-temazepam }\end{array}$ & $\begin{array}{l}\text { Serotonin syndrome } \\
\text { Toxicity to various agents } \\
\text { Pulmonary edema }\end{array}$ & DE, OT & Other HP \\
\hline 15 & 28 & M & Australia & $\begin{array}{l}\text { PS-citalopram } \\
\text { SS-MDMA } \\
\text { SS- 7-aminoflunitrazepam } \\
\text { SS-amphetamine } \\
\text { SS-codeine } \\
\text { SS-Methamphetamine } \\
\text { SS-morphine } \\
\text { SS-THC }\end{array}$ & $\begin{array}{l}\text { Serotonin syndrome } \\
\text { Toxicity to various agents }\end{array}$ & DE, OT & Other HP \\
\hline 16 & 34 & M & Australia & $\begin{array}{l}\text { PS-Citalopram } \\
\text { SS-MDMA } \\
\text { SS- 6-monoacetylmorphine } \\
\text { SS-ethanol }\end{array}$ & $\begin{array}{l}\text { Hepatic steatosis } \\
\text { Prostatitis } \\
\text { Serotonin Syndrome } \\
\text { Toxicity to various agents }\end{array}$ & DE, OT & Other HP \\
\hline
\end{tabular}


TABLE 1 | Continued

\begin{tabular}{|c|c|c|c|c|c|c|c|}
\hline & Age & Sex & Country & $\begin{array}{l}\text { Concomitant } \\
\text { medications }\end{array}$ & Adverse events & Outcome & Reported by \\
\hline 17 & 16 & M & US & $\begin{array}{l}\text { PS- methamphetamine } \mathrm{HCl} \\
\text { SS-MDMA }\end{array}$ & $\begin{array}{l}\text { Accidental death } \\
\text { Disseminated intravascular } \\
\text { coagulation } \\
\text { Encephalopathy } \\
\text { Hemodialysis } \\
\text { Hepatorenal failure } \\
\text { Hyperthermia malignant } \\
\text { Hypoglycemia } \\
\text { Hypotension } \\
\text { Hypoxic ischemic } \\
\text { encephalopathy } \\
\text { Multi organ failure } \\
\text { Multiple drug overdose } \\
\text { Muscle rigidity } \\
\text { Renal failure } \\
\text { Rhabdomyolysis } \\
\text { Serotonin syndrome } \\
\text { Shock } \\
\text { Tremor } \\
\text { Unresponsive to stimuli }\end{array}$ & $\mathrm{DE}$ & MD \\
\hline $18^{\star}(2)$ & 41 & M & US & $\begin{array}{l}\text { PS-desvenlafaxine } \\
\text { SS-Risperidone } \\
\text { I-MDMA }\end{array}$ & $\begin{array}{l}\text { Acute kidney injury } \\
\text { Aggression } \\
\text { Blood sodium decreased } \\
\text { Drug interaction } \\
\text { Hemodialysis } \\
\text { Rhabdomyolysis } \\
\text { Serotonin syndrome }\end{array}$ & $\mathrm{HO}, \mathrm{OT}$ & Other HP \\
\hline 19 & unknown & & France & $\begin{array}{l}\text { PS-fentanyl } \\
\text { SS-buprenorphine } \\
\text { SS-cannabis } \\
\text { SS-cocaine } \\
\text { SS-codeine } \\
\text { SS-MDMA } \\
\text { SS-heroin } \\
\text { SS-hydromoprhone } \\
\text { SS-methadone } \\
\text { SS-morphine } \\
\text { SS-Oxycodone } \\
\text { SS-remifentanyl }\end{array}$ & Serotonin syndrome & OT & Other HP \\
\hline $20^{*}(9)$ & 17 & $\mathrm{~F}$ & France & $\begin{array}{l}\text { PS-fluoxetine } \\
\text { SS-aripiprazole } \\
\text { SS-diazepam } \\
\text { SS-olanzapine } \\
\text { SS-amphetamine } \\
\text { SS-cannabis } \\
\text { SS-MDMA }\end{array}$ & $\begin{array}{l}\text { Serotonin syndrome } \\
\text { Somnolence } \\
\text { Tachycardia } \\
\text { Miosis } \\
\text { Agitation } \\
\text { Intentional overdose }\end{array}$ & $\mathrm{HO}$ & $\begin{array}{l}\text { Consumer } \\
\text { Pharmacist } \\
\text { Other HP }\end{array}$ \\
\hline
\end{tabular}

PS, primary suspect; SS, secondary suspect; I, interacting C-concomitant; HO, hospitalization; C, concomitant; OT, Other Serious (Important Medical Event); DE, death; CN, consumer; $H$, health professional; MD, doctor of medicine.

* (), number of duplicates.

should not be confused with absolute population incidences. Most of the cases are not clinically assessed for causality, and detailed case narratives are not provided to maintain patient privacy and protected health information. There was no consistent means for reporters to provide information on drug identification or detection.

Nineteen out of the 20 presented case reports were submitted by healthcare professionals (Form-3500), with the reported outcome of either death or hospitalization, wherein it is standard clinical practice to administer drug tests to identify cause of toxicity. However, since manufacture and distribution of MDMA is not regulated, it is still uncertain whether material included in the cases could be confirmed as MDMA or MDMA laced with another compound. SSRIs' protective effects on the pharmacodynamic effects of MDMA have been well-documented (39-42). Although SSRis were 
TABLE 2 | Psychoactive concomitant drugs, summarized by class, in serotonin syndrome/MDMA cases.

\begin{tabular}{|c|c|c|c|c|c|c|c|c|c|c|c|c|}
\hline MDMA & Amphetamines & MAOI & SSRI & SNRI & $\begin{array}{l}\text { 2nd gen } \\
\text { antipsychotic }\end{array}$ & $\begin{array}{l}\text { Cannabis or } \\
\text { THC }\end{array}$ & Cocaine & $\begin{array}{l}\text { Benzodiazepines and } \\
\text { GABA modulators }\end{array}$ & Opioids & Alcohol & $\begin{array}{l}\text { Ergot } \\
\text { alkaloids, } \\
\text { triptans }\end{array}$ & Ketamine \\
\hline * & & & & & $* \star \star *$ & & & ** & & & & \\
\hline * & & & & & & * & & * & * & & * & \\
\hline * & & & & & & & & & * & & & \\
\hline * & ** & * & & & & & & & & & & \\
\hline * & * & & & & & & & & & & & \\
\hline * & ** & * & & & & * & & & & & & \\
\hline * & $* *$ & & & & & & & & & & & \\
\hline * & & * & & & & & & * & * & & & \\
\hline * & ** & & & & & * & * & & * & & & \\
\hline * & * & & * & & & * & & & & * & & \\
\hline * & & * & * & & & & * & & & & & \\
\hline * & * & & & & & & & ** & * & & & \\
\hline * & * & & & & & * & & $* *$ & * & & & \\
\hline * & $* *$ & & ** & & & & & ** & ** & & & * \\
\hline * & ** & & * & & & * & & * & ** & & & \\
\hline * & & & * & & & & & & * & * & & \\
\hline * & * & & & & & & & & & & & \\
\hline * & & & & * & * & & & & & & & \\
\hline * & & & & & & * & * & & 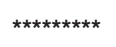 & & & \\
\hline * & * & & * & & ** & * & & * & & & & \\
\hline
\end{tabular}


present in six of the presented cases, all of the reports listed additional substances as well. Due to the low number of MDMA+SSRI SS cases in FAERS, this relationship was challenging to quantify.

\section{CONCLUSION}

In summary, reported use of MDMA as the sole administered drug produced no reports of SS in the FAERS system; it was far more common for this syndrome to arise when MDMA was reportedly combined with an additional substance, including psychostimulants, opioids, and antidepressants. In clinical trials of MDMA-assisted therapy, participants are tapered off serotonergic drugs prior to administration of MDMA. The current findings in the FAERS system are in line with the failure of clinical trials where MDMA is investigated in conjunction with therapy to report SS.

\section{DATA AVAILABILITY STATEMENT}

The datasets presented in this study can be found in online repositories. The names of the repository/repositories and accession number(s) can be found below: https://www.fda.gov/ drugs/questions-and-answers-fdas-adverse-event-reporting-

\section{REFERENCES}

1. Mitchell JM, Bogenschutz M, Lilienstein A, Harrison C, Kleiman S, ParkerGuilbert K, et al. MDMA-assisted therapy for severe PTSD: a randomized, double-blind, placebo-controlled phase 3 study. Nat Med. (2021) 27:102533. doi: 10.1038/s41591-021-01336-3

2. Wolfson PE, Andries J, Feduccia AA, Jerome L, Wang JB, Williams E, et al. MDMA-assisted psychotherapy for treatment of anxiety and other psychological distress related to life-threatening illnesses: a randomized pilot study. Sci Rep. (2020) 10:20442. doi: 10.1038/s41598-020-75706-1

3. Mithoefer MC, Feduccia AA, Jerome L, Mithoefer A, Wagner M, Walsh $Z$, et al. MDMA-assisted psychotherapy for treatment of PTSD: study design and rationale for phase 3 trials based on pooled analysis of six phase 2 randomized controlled trials. Psychopharmacology. (2019) 236:273545. doi: 10.1007/s00213-019-05249-5

4. Jerome L, Feduccia AA, Wang JB, Hamilton S, Yazar-Klosinski B, Emerson A, et al. Long-term follow-up outcomes of MDMA-assisted psychotherapy for treatment of PTSD: a longitudinal pooled analysis of six phase 2 trials. Psychopharmacology. (2020) 237:2485-97. doi: 10.1007/s00213-020-05548-2

5. Kalant H. The pharmacology and toxicology of "ecstasy" (MDMA) and related drugs. CMAJ. (2001) 165:917-28.

6. Meyer JS. 3,4-methylenedioxymethamphetamine (MDMA): current perspectives. Subst Abuse Rehabil. (2013) 4:83-99. doi: 10.2147/SAR.S37258

7. Simmler LD, Buser TA, Donzelli M, Schramm Y, Dieu LH, Huwyler J, et al. Pharmacological characterization of designer cathinones in vitro. $\mathrm{Br} J$ Pharmacol. (2013) 168:458-70. doi: 10.1111/j.1476-5381.2012.02145.x

8. Verrico CD, Miller GM, Madras BK. MDMA (Ecstasy) and human dopamine, norepinephrine, and serotonin transporters: implications for MDMA-induced neurotoxicity and treatment. Psychopharmacology. (2007) 189:489-503. doi: 10.1007/s00213-005-0174-5

9. Bershad AK, Miller MA, Baggott MJ, de Wit H. The effects of MDMA on socio-emotional processing: does MDMA differ from other stimulants? J Psychopharmacol. (2016) 30:1248-58. doi: 10.1177/0269881116663120

10. Yazar-Klosinski BB, Mithoefer MC. Potential psychiatric uses for MDMA. Clin Pharmacol Ther. (2017) 101:194-6. doi: 10.1002/cpt.565 system-faers/fda-adverse-event-reporting-system-faers-latestquarterly-data-files.

\section{ETHICS STATEMENT}

Ethical review and approval was not required for the study on human participants in accordance with the local legislation and institutional requirements. Written informed consent from the participants' legal guardian/next of kin was not required to participate in this study in accordance with the national legislation and the institutional requirements.

\section{AUTHOR CONTRIBUTIONS}

TM performed the research. TM, LJ, RA, and AB designed the study, drafted the manuscript, and reviewed the final version. RA processed the data sets. AB supervised the study. All authors contributed to the article and approved the submitted version.

\section{FUNDING}

The study was funded by MAPS Public Benefit Corporation and in part by Skaggs School of Pharmacy and Pharmaceutical Sciences, UC San Diego Health.

11. Hysek CM, Schmid Y, Simmler LD, Domes G, Heinrichs M, Eisenegger C, et al. MDMA enhances emotional empathy and prosocial behavior. Soc Cogn Affect Neurosci. (2014) 9:1645-52. doi: 10.1093/scan/nst161

12. Vizeli P, Liechti ME. Safety pharmacology of acute MDMA administration in healthy subjects. J Psychopharmacol. (2017) 31:576-88. doi: 10.1177/0269881117691569

13. Francescangeli J, Karamchandani K, Powell M, Bonavia A. The Serotonin Syndrome: from molecular mechanisms to clinical practice. Int J Mol Sci. (2019) 20:2288. doi: 10.3390/ijms20092288

14. Boyer EW, Shannon M. The serotonin syndrome. N Engl J Med. (2005) 352:1112-20. doi: 10.1056/NEJMra041867

15. Dobry Y, Rice T, Sher L. Ecstasy use and serotonin syndrome: a neglected danger to adolescents and young adults prescribed selective serotonin reuptake inhibitors. Int J Adolesc Med Health. (2013) 25:1939. doi: 10.1515/ijamh-2013-0052

16. Silins E, Copeland J, Dillon P. Qualitative review of serotonin syndrome, ecstasy (MDMA) and the use of other serotonergic substances: hierarchy of risk. Aust $N$ Z J Psychiatry. (2007) 41:649-55. doi: 10.1080/00048670701449237

17. Pilgrim JL, Gerostamoulos D, Drummer OH. Deaths involving MDMA and the concomitant use of pharmaceutical drugs. J Anal Toxicol. (2011) 35:21926. doi: 10.1093/anatox/35.4.219

18. Pilgrim JL, Gerostamoulos D, Woodford N, Drummer OH. Serotonin toxicity involving MDMA (ecstasy) and moclobemide. Forensic Sci Int. (2012) 215:184-8. doi: 10.1016/j.forsciint.2011.04.008

19. Houlihan DJ. Serotonin syndrome resulting from coadministration of tramadol, venlafaxine, and mirtazapine. Ann Pharmacother. (2004) 38:4113. doi: 10.1345/aph.1D344

20. Mahlberg R, Kunz D, Sasse J, Kirchheiner J. Serotonin syndrome with tramadol and citalopram. Am J Psychiatry. (2004) 161:1129. doi: 10.1176/appi.ajp.161.6.1129

21. Khan S, Saud S, Khan I, Asif M, Ismail O, Salam A, et al. serotonin syndrome presenting with concomitant tramadol and diphenhydramine use: a case report of an unlikely side-effect. Cureus. (2018) 10:e2421. doi: 10.7759/cureus.2421 
22. Bergeron L, Boulé $M$, Perreault S. Serotonin toxicity associated with concomitant use of linezolid. Ann Pharmacother. (2005) 39:956-61. doi: 10.1345/aph.1E523

23. Lee J, Franz L, Goforth HW. Serotonin syndrome in a chronic-pain patient receiving concurrent methadone, ciprofloxacin, and venlafaxine. Psychosomatics. (2009) 50:638-9. doi: 10.1016/S0033-3182(09)70868-0

24. Haslett CD, Kumar S. Can olanzapine be implicated in causing serotonin syndrome? Psychiatry Clin Neurosci. (2002) 56:5335. doi: 10.1046/j.1440-1819.2002.01050.x

25. Martin A, Naunton M, Kosari S, Peterson G, Thomas J, Christenson JK. Treatment guidelines for PTSD: a systematic review. J Clin Med. (2021) 10:4175. doi: $10.3390 / \mathrm{jcm} 10184175$

26. Ehret M. Treatment of posttraumatic stress disorder: focus on pharmacotherapy. Ment Health Clin. (2019) 9:37382. doi: 10.9740/mhc.2019.11.373

27. Simmons S, Suárez L. Substance abuse and trauma. Child Adolesc Psychiatr Clin N Am. (2016) 25:723-34. doi: 10.1016/j.chc.2016.05.006

28. Campbell DG, Felker BL, Liu CF, Yano EM, Kirchner JE, Chan D, et al. Prevalence of depression-PTSD comorbidity: implications for clinical practice guidelines and primary care-based interventions. J Gen Intern Med. (2007) 22:711-8. doi: 10.1007/s11606-006-0101-4

29. Knowles KA, Sripada RK, Defever M, Rauch SAM. Comorbid mood and anxiety disorders and severity of posttraumatic stress disorder symptoms in treatment-seeking veterans. Psychol Trauma. (2019) 11:4518. doi: $10.1037 /$ tra0000383

30. Koffel E, Khawaja IS, Germain A. Sleep disturbances in posttraumatic stress disorder: updated review and implications for treatment. Psychiatr Ann. (2016) 46:173-6. doi: 10.3928/00485713-2016 0125-01

31. Kind S, Otis JD. The interaction between chronic pain and PTSD. Curr Pain Headache Rep. (2019) 23:91. doi: 10.1007/s11916-019-0828-3

32. Craigle V. MedWatch: the FDA safety information and adverse event reporting program. J Med Libr Assoc. (2007) 95:2245. doi: 10.3163/1536-5050.95.2.224

33. Kessler DA. Introducing MEDWatch. A new approach to reporting medication and device adverse effects and product problems. JAMA. (1993) 269:2765-8. doi: 10.1001/jama.269.21.2765

34. Makunts T, Saunders IM, Cohen IV, Li M, Moumedjian T, Issa MA, et al. Myocarditis occurrence with cancer immunotherapy across indications in clinical trial and post-marketing data. Sci Rep. (2021) 11:17324. doi: 10.1038/s41598-021-96467-5

35. Cohen IV, Makunts T, Abagyan R, Thomas K. Concomitant drugs associated with increased mortality for MDMA users reported in a drug safety surveillance database. Sci Rep. (2021) 11:5997. doi: 10.1038/s41598-021-85389-x
36. de la Torre R, Yubero-Lahoz S, Pardo-Lozano R, Farré M. MDMA, methamphetamine, and CYP2D6 pharmacogenetics: what is clinically relevant? Front Genet. (2012) 3:235. doi: 10.3389/fgene.2012.00235

37. Rodgers JT, Davydova NY, Paragas EM, Jones JP, Davydov DR. Kinetic mechanism of time-dependent inhibition of CYP2D6 by 3,4methylenedioxymethamphetamine (MDMA): functional heterogeneity of the enzyme and the reversibility of its inactivation. Biochem Pharmacol. (2018) 156:86-98. doi: 10.1016/j.bcp.2018.08.010

38. UN. World Drug Report 2021 (2021).

39. Farré M, Abanades S, Roset PN, Peiró AM, Torrens M, O'Mathúna B, et al. Pharmacological interaction between 3,4-methylenedioxymethamphetamine (ecstasy) and paroxetine: pharmacological effects and pharmacokinetics. $J$ Pharmacol Exp Ther. (2007) 323:954-62. doi: 10.1124/jpet.107.129056

40. Liechti ME, Baumann C, Gamma A, Vollenweider FX. Acute psychological effects of 3,4-methylenedioxymethamphetamine (MDMA, "Ecstasy") are attenuated by the serotonin uptake inhibitor citalopram. Neuropsychopharmacology. (2000) 22:51321. doi: 10.1016/S0893-133X(99)00148-7

41. Liechti ME, Vollenweider FX. The serotonin uptake inhibitor citalopram reduces acute cardiovascular and vegetative effects of 3,4methylenedioxymethamphetamine ('Ecstasy') in healthy volunteers. J Psychopharmacol. (2000) 14:269-74. doi: 10.1177/026988110001400313

42. Tancer M, Johanson CE. The effects of fluoxetine on the subjective and physiological effects of 3,4-methylenedioxymethamphetamine (MDMA) in humans. Psychopharmacology. (2007) 189:56573. doi: $10.1007 /$ s00213-006-0576-z

Conflict of Interest: The authors declare that the research was conducted in the absence of any commercial or financial relationships that could be construed as a potential conflict of interest.

Publisher's Note: All claims expressed in this article are solely those of the authors and do not necessarily represent those of their affiliated organizations, or those of the publisher, the editors and the reviewers. Any product that may be evaluated in this article, or claim that may be made by its manufacturer, is not guaranteed or endorsed by the publisher.

Copyright (C) 2022 Makunts, Jerome, Abagyan and de Boer. This is an open-access article distributed under the terms of the Creative Commons Attribution License (CC $B Y)$. The use, distribution or reproduction in other forums is permitted, provided the original author(s) and the copyright owner(s) are credited and that the original publication in this journal is cited, in accordance with accepted academic practice. No use, distribution or reproduction is permitted which does not comply with these terms. 